\title{
Italian Dictionaries of Abbreviations and the Preparation of Entries of the Italian-Slovene Dictionary of Abbreviations
}

\author{
Mojca Kompara Lukančič, Faculty of Criminal Justice and Security \\ and Faculty of Tourism, University of Maribor, Slovenia \\ (mojca.kompara@gmail.com) (mojca.kompara@um.si)
}

\begin{abstract}
The present article addresses the two contemporary Italian dictionaries of abbreviations Malossini (1999) and Righini (2001) and outlines the position of the Italian abbreviations in some other Italian dictionaries, namely the monolingual Zingarelli (2000) and Garzanti (2021) and bilingual Slovene-Italian (Šlenc 2006) and Italian-Slovene (Šlenc 1997). The aim of the paper is to give an insight into the compilation of the abbreviation dictionary entries in monolingual Italian, bilingual in tandem with the Slovene language and specialised abbreviation dictionaries; highlight the elements present within the dictionary entries; present the deficiencies in compiling and examples of good practice; with the aim of introducing the outcomes in the compilation of the bilingual Italian-Slovene dictionary entries of the Slovene Contemporary Dictionary of Abbreviations. Within the paper we present the composition of the bilingual dictionary entries giving the reader an insight into the elements of the dictionary entry, namely the usage of language and field qualifiers, articulated prepositions, i.e. preposizioni articolate (composed of prepositions and definite articles), official translations and additional descriptions.
\end{abstract}

Keywords: ABBREVIATIONS, BILINGUAL DICTIONARIES, COMPILATION, DICTIONARIES, DICTIONARY ENTRY, EXPANSION, ITALIAN, LEXICOGRAPHY, SLOVENE, SPECIALISED DICTIONARIES

Opsomming: Italiaanse afkortingswoordeboeke en die voorbereiding van inskrywings van die Italiaans-Sloweense afkortingswoordeboek. In hierdie artikel word die twee hedendaagse Italiaanse afkortingswoordeboeke Malossini (1999) en Righini (2001) aangespreek en word die stand van Italiaanse afkortings in sommige ander Italiaanse woordeboeke, naamlik die eentalige Zingarelli (2000) en Garzanti (2021) en die tweetalige Sloweens-Italiaanse (Šlenc 2006) en Italiaans-Sloweense (Šlenc 1997) woordeboeke bespreek. Die doel van die artikel is om die samestelling van die afkortingswoordeboekinskrywings in eentalig Italiaanse, tweetalig Sloweens-Italiaanse/Italiaans-Sloweense en gespesialiseerde afkortingswoordeboeke weer te gee; om die elemente waaruit die woordeboekinskrywings bestaan, uit te lig; om die leemtes in die samestelling asook voorbeelde van goeie praktyk te beskryf; om sodoende die resultate in 
die samestelling van die tweetalige Italiaans-Sloweense woordeboekinskrywings van die Sloweense Kontemporêre Afkortingswoordeboek toe te pas. In die artikel word die samestelling van die tweetalige woordeboekinskrywings weergegee om die leser insig te gee in die elemente van die woordeboekinskrywing, naamlik die gebruik van taal- en veldbepalers, geartikuleerde voorsetsels, m.a.w. preposizioni articolate (saamgestel uit voorsetsels en bepaalde lidwoorde), amptelike vertalings en addisionele beskrywings.

Sleutelwoorde: AFKORTINGS, TWEETALIGE WOORDEBOEKE, SAMESTELLING, WOORDEBOEKE, WOORDEBOEKINSKRYWING, UITBREIDING, ITALIAANS, LEKSIKOGRAFIE, SLOWEENS, GESPESIALISEERDE WOORDEBOEKE

\section{Introduction}

Abbreviations - grouped, joined, unified compositions of letters - often taken from full words of phrases (Kompara 2018) present in almost any language have the ability to materialise when needed i.e. COVID-19 (COrona VIrus Disease), SARS (Severe acute respiratory syndrome), etc. and vanish when not needed anymore, i.e. in the case of company names such as Beti (Belokranjska trikotažna industrija), or political parties such as LDS (Liberalna demokracija Slovenije). The issue of the formation of new abbreviations in the Slovene language without being properly normed has been thoroughly discussed by Kompara Lukančič (2018, 2017, 2009) Logar (2005) Verovnik and Logar (2006) and Verovnik (2018) and Fajfar and Žagar Karer (2015). Given the absence of such a publication (Kompara Lukančič 2018, 2017), we compiled a Slovene Contemporary Dictionary of Abbreviations which is currently in the reviewing process. In order to present the process of creating such a dictionary, in the present paper we address the position of abbreviations in the Italian dictionaries of abbreviations, monolingual and bilingual dictionaries, which has led to the preparation of the Italian-Slovene dictionary entries in the Slovene Contemporary Dictionary of Abbreviations. The Italian-Slovene dictionary is a part of the Slovene Contemporary Dictionary of Abbreviations which comprises over 20 languages, among them the Italian language is on the third position, preceded by English and Slovene. Within the paper we give an overview to the characteristics of the dictionary entries of the Italian dictionaries of abbreviations from Malossini (1999) and Righini (2001) and outline the position of the Italian abbreviations in some other Italian dictionaries, namely the monolingual Zingarelli (2000) and Garzanti (2021) and bilingual Slovene-Italian (Šlenc 2006) and Italian-Slovene (Šlenc 1997), and present the Italian-Slovene dictionary entries in the Slovene Contemporary Dictionary of Abbreviations.

\section{Italian dictionaries of abbreviations}

In Italian, dictionaries of abbreviations are not as common as in English (Kom- 
para Lukančič 2020), but we can still rely on two works that give a relatively contemporary insight into abbreviations and were published in a rather similar time frame, Malossini in 1999 and Righini in 2001. Due to the fact that both dictionaries were published twenty years ago, we cannot expect to find up-todate abbreviations, i.e. COVID, but they still give an insight into the hidden meaning, often not visible in the abbreviated letters, of abbreviations providing the reader with numerous expansions. In the Italian dictionaries of abbreviations, a random sampling method was used.

\section{DidiSi - Dizionario di Sigle Abbreviazioni e Simboli (Righini 2001)}

Dizionario di Sigle Abbreviazioni e Simboli - DidiSi (Righini 2001) is an Italian dictionary of abbreviations that includes over 10,000 alphabetically ordered Italian and foreign abbreviations in 14 different languages and over 30,000 expansions. Prior to the preface there is a list of 68 abbreviations used within the dictionary entries, denominating mainly language and field qualifiers, i.e. it. - italiano (Italian), chim. - chimica (chemistry). In the preface there is a short and very generic introduction to abbreviations, followed by a short introduction to the usage of the present dictionary. The dictionary is only available in paper format. Within the introduction on how to use the dictionary, the author mentions that abbreviations are not organised in the same way as normal language, as they follow their own rules of formation and consequently the way of reporting is, especially in the press, all uppercase or lowercase letters, with the occurrence of different layouts i.e. italics, bold, etc. Righini (2001) argues that in the dictionary entry the abbreviations are presented as uppercase, bold headwords. Foreign abbreviations are followed by the source languages, the field qualifiers and the translations into Italian, and some additional information when needed. The dictionary entries expand over 270 pages. Below the most representative general and specific characteristics of the dictionary entries, in alphabetic order, are explained.

\section{Example 1}

A 1 altezza / area. 2 (fis.) ampere. 3 atomica (bomba). 4 amplificazione. 5 Austria (anche targa autom.). 6 nell'alpinismo, seguita da un numero, indica il grado di difficoltà della scalata artificiale. $7 \mathrm{ingl}$. Ace (asso, nelle carte da poker e da ramino). 8 (biol.) Adenina, base purinica del DNA e RNA. 9 Autostrada / ted. Autobahn / fr. Autoroute. 10 (banca) Azione. 11 (anat.) Arteria. 12 Alfiere (nel gioco degli scacchi). 13 (ferr.) Automotrice. 14 (meteor.) centro di Alta Pressione. 15 Alfa (A nella compitazione internazionale) / Ancona (A nella compitazione italiana). 
Cf. the following examples 1, the entry is composed of an abbreviation written in bold, i.e. A, and followed by numerically ordered expansions or meanings. The Arabic numbers are written in bold and italics and are followed by expansion(s), which, in some synonymous cases, are divided by a slash, i.e. 9 Autostrada / ted. Autobahn / fr. Autoroute (highway). Every single expansion terminates with full stop. As seen from example 1, for some expansions, mainly the specialised ones, the field qualifier is also provided, i.e. 2 (fis.) ampere, where (fis.) denominates physics. The list of field qualifiers is given at the beginning of the dictionary, prior to the preface or introduction to the dictionary. With the dictionary entry the field qualifiers are given in brackets, usually clipped, in italics and positioned prior to the expansion, i.e. (fis.) physics, (anat.) anatomy. As seen from example 1 additional information is also present within the dictionary entry, i.e. 3 atomica (bomba) (atomic bomb) and it follows the expansion, in brackets and italics. The additional information is provided as a simple word (bomba) bomb or as a whole explanatory sentence (anche targa autom.) (also car plate), where the final word is clipped. In example 1 expansion 6, i.e. 6 nell'alpinismo, seguita da un numero, indica il grado di difficoltà della scalata artificiale (in mountaineering, followed by a number, it indicates the degree of difficulty of the artificial climb) we notice only the explanatory sentence written in italics giving detailed information about the usage of the abbreviation. Another way of providing additional information is seen in expansion 8, i.e. 8 (biol.) Adenina, base purinica del DNA e RNA (Adenine, purine base of DNA and RNA), where the explanatory sentence is not in brackets but follows the expansion, is divided by a comma and is written in italics. We have to mention another way of providing additional information, namely expansion 14, i.e. 14 (meteor.) centro di Alta Pressione (High Pressure center), where we notice that the additional information is provided in italics within the expansion. In expansion 10, i.e. 10 (banca) Azione (stock), we notice some inconsistency in providing the additional information (banca) (bank). We do not know if it functions as a field qualifier, but it should be abbreviated and the word is not included in the list of abbreviations used in the dictionary, or as additional information, that according to expansion 3 should be placed after the expansion. Within the dictionary entry we also notice the introduction of language qualifiers, i.e. $7 \mathrm{ingl}$. Ace (asso, nelle carte da poker e da ramino) (ace, in poker and rummy cards), which are positioned prior to the expansion, are abbreviated and written in italics, i.e. ingl. (English). In cases where the same abbreviation is used in more than one language the Italian expansion appears in the first position, followed by the expansions in foreign languages, i.e. 9 Autostrada / ted. Autobahn / fr. Autoroute (highway), as seen from the example, the expansions are divided by a dash and the alphabetic order of the foreign expansions is not preserved, as the German expansion is placed prior to the French. 


\section{Example 2}

ACI 1 Automobile club d'Italia. 2 Azione Cattolica Italiana. 3 Associazione Cartografica Internazionale. 4 Aero Club Italiano $o$ d'Italia $=$ AeCI. 5 Associazione Culturale Italiana / Alleanza Culturale Internazionale. 6 Aviazione Civile Italiana / Aviazione Civile Internazionale. $7 \mathrm{ingl}$. Airports Council International (Consiglio internazionale degli aeroporti). 8 Alleanza Cooperativa Internazionale.

\section{Example 3}

AeCI Aero Club Italiano $o$ d'Italia

As seen from example 2, within the dictionary entry in expansion 4, i.e. 4 Aero Club Italiano $o$ d'Italia $=\mathbf{A e C I}$ (Italian Aero Club or Aero Club from Italy), there is the occurrence of two expansions of the same concept, namely Aero Club Italiano (Italian Aero Club) and Aero Club d'Italia (Aero Club from Italy) followed by the abbreviation that is also used in Italian for this concept after the symbol =, i.e. $=$ AeCI. In example 3 we notice some inconsistency in providing the crossreference, as the abbreviation ACI is not mentioned within the dictionary entry.

\section{Example 4}

ACNUR Alto Commissario delle Nazioni Unite per i Rifugiati = UNHCR.

Within the dictionary entries we notice Italian and foreign abbreviations, in example 4 we notice the introduction of an Italian abbreviation, ACNUR that was originally English, i.e. UNHCR. As seen from the dictionary entry the expansion in Italian is followed by the symbol = and the original abbreviation UNHCR. A cross-reference is also provided as seen in example 5, where some inconsistency in spelling, namely the uppercase letters, i.e. Alto Commissario and Rifugiati (High Commissioner and Refugees) in example 4 vs the lowercase letters, i.e. alto commissariato and rifugiati (High Commissariat and Refugees) in example 5 as well as the occurrence of two different nouns, namely Commissario (Commissioner) and commissariato (Commissariat) is visible.

\section{Example 5}

UNHCR ingl. United Nations High Commissioner for Refugees (alto commissariato delle Nazioni Unite per i rifugiati = ACNUR). 


\section{Some interesting example pairs of abbreviations}

Below some particular example pairs of abbreviations are presented within joint examples from 6 up to example 10.

\section{Example 6}

A.C. di G. Alta Corte di Giustizia

BdS Banco di Sicilia

In example 6 there are two abbreviations composed of a preposition, namely di (of, from), that in the abbreviation A.C. di G. is fully spelt out, while in BdS it is abbreviated and forms a unified abbreviation.

\section{Example 7}

ACMONITAL ACciaio MONetraio ITALiano.

ACOSER Azienda COnsorziale SErvizi Reno (Bologna) oggi SEABO.

ACOTRAL Azienda COnsortile TRAsporti Laziali oggi COTRAL.

In example 7 we encounter examples of acronyms, i.e. ACMONITAL ACciaio MONetraio ITALiano (name of a company), clipped to the first two or three letters. Such type of formation of abbreviations also used to be popular in Slovenia, i.e. Beti, Nama, etc. (Gložančev 1980). In example 7 we also notice the occurrence of acronyms that are outdated and at present a different abbreviation is used and introduced within the dictionary entry with the word oggi, (today), i.e. ACOSER Azienda COnsorziale SErvizi Reno (Bologna) oggi SEABO name of a company), and ACOTRAL Azienda COnsortile TRAsporti Laziali oggi COTRAL (name of a company). Cross-references are ensured as both abbreviations, namely COTRAL and SEABO, are included as separate dictionary entries.

\section{Example 8}

ACL (elettron.) fr. Affichage à Cristaux Liquides (visualizzazione a cristalli liquidi) $=$ LCD.

LCD (elettron.) ingl. Liquid Crystal Display (visualizzazione, schermo a cristalli liquidi).

Some inconsistency is seen in example 8 where for the French abbreviation ACL, composed of field and French language qualifier, followed by the French 
expansion, the Italian explanation in brackets (visualizzazione a cristalli liquidi) (liquid crystal display), is provided, followed by a special symbol $=$, followed by the abbreviation LCD, that seems to be Italian, but is actually an English abbreviation. This is also seen in the cross-reference entry LCD where the entry is composed of an English language qualifier and consequently an English expansion. We also notice a difference in meaning provided in the Italian translation or explanation compared to ACL, namely (visualizzazione, schermo a cristalli liquidi), (display, liquid crystal screen). The usage of the special symbol = is not explained in the preface. In examples 2 and 5 the $=$ symbol is followed by the Italian equivalent of the abbreviation, but in examples 4 and 8 , the same symbol is followed by the English equivalent.

\section{Example 9}

Bbk, BBk ted. Deutsche Bundesbank (banca federale tedesca) = BUBA.

Bu.Ba., Buba 1 (pop.) ted. Deutsche Bundesbank (Banca federale tedesca = Bbk). 2 Bundesbahn (ferrovie federali tedesche).

In example 9 we notice some inconsistency in the two dictionary entries that should function as cross-references. The dictionary entry Bbk, BBk is followed by a language qualifier, the German expansion and in brackets the Italian explanation, followed by the special symbol $=$ and the equivalent BUBA. Within the dictionary we do not find the dictionary entry for the abbreviation BUBA, but we encounter a differently spelt dictionary entry, namely Bu.Ba., Buba that has two expansions. Within the first expansion we notice the same abbreviation meaning. The entry is composed of the usage of a field qualifier (pop.) denominating popolare or popolarmente (popular or popularly), that is not included in the entry Bbk, BBk, followed by the language qualifier ted., the German expansion and the Italian explanation or translation in brackets (Banca federale tedesca $=$ Bbk) (German federal bank), that is different from the explanation in the expansion of the entry Bbk, BBk. The difference is seen in the usage of a capitalised noun, banca vs Banca, and the occurrence of the equivalent Bbk in brackets in the dictionary entry Bu.Ba., Buba. The abbreviations are not systematically presented, in the entry Bbk, BBk, where the headword functions as a synonym the equivalent is BUBA and not Buba as suggested by the cross-reference. In the cross-reference entry Bu.Ba., Buba, where the headword functions as a synonym, after the Italian explanation and symbol there is only the abbreviation Bbk mentioned. Also, in the entry Bbk, BBk the equivalent abbreviation BUBA is not within brackets, in the entry Bu.Ba., Buba the equivalent Bbk is within brackets. 


\section{Example 10}

BO 1 Bologna. 2 ingl. Box Office (botteghino di cinema o teatro). 3 ingl. Body Odour (odore del corpo, nel senso di odore sgradevole). $4 \mathrm{sp}$. Boletín Oficial (Gazzetta ufficiale della Spagna) $=$ BOE.

BOE 1 ing. Barrel Oil Equivalent (equivalente di un barile di petrolio, unità di riferimento per altri combustibili). $2 \mathrm{sp}$. Boletín Oficial del Estado (gazzetta ufficiale dello Stato).

Some inconsistency is also seen in example 10 where in the dictionary entry $\mathbf{B O}$, i.e. $4 \mathrm{sp}$. Boletín Oficial (Gazzetta ufficiale della Spagna) = BOE (Spanish official gazette) after the language qualifier and expansion, in brackets we notice the explanation or translation, namely Gazzetta ufficiale della Spagna (Spanish official gazette) that is followed by symbol $=$ and the equivalent abbreviation BOE. In the cross-reference dictionary entry BOE in the second expansion we notice, i.e. $2 \mathrm{sp}$. Boletín Oficial del Estado (gazzetta ufficiale dello Stato) (Official gazette of the state) that is composed of language qualifier, followed by the expansion that is slightly different from the one in BO, but preserves the same meaning, and in brackets the explanation or translation, namely gazzetta ufficiale dello Stato (Official gazette of the state) where we notice that the word gazzetta (gazette) is not capitalised, but the word Stato (state) is. It is not clear why the explanation or transition is provided in such way. We also notice the absence of the equivalent abbreviation BO in the entry BOE. Consequently, cross-referencing is not adequately presented.

Below, as exceptions, the explanations of two culturally and historically specific abbreviations are presented.

\section{Example 11}

EUR 1 Esposizione Universale di Roma (prevista nel 1942, non tenuta a causa della guerra). 2 oggi il quartiere residenziale sorto in quella zona. 3 abbreviazione ufficiale della moneta euro (dal $1^{\circ}$ gennaio 1999 in tutti gli Stati partecipanti), obbligatoriamente tutta maiuscola.

In example 11 we notice the occurrence of historically labelled abbreviations, namely in the first expansion, i.e. 1 Esposizione Universale di Roma (prevista nel 1942, non tenuta a causa della guerra) (Universal Exposition of Rome, scheduled for 1942, not held due to war), where an explanatory sentence is provided stating that the event was never performed, but the abbreviation was still used enough to be included in the present dictionary. Within the second expansion, i.e. 2 oggi il quartiere residenziale sorto in quella zona (today the residential district built in that area), we notice the time qualifier oggi (today) and an explanatory sentence 
stating that the abbreviation EUR meant the Universal Exhibition in Rome, Esposizione Universale di Roma but was transferred to the present residential area of the aforementioned exhibition. The expansion denoting the currency, in use in Italy since 1999, is only placed as the 3rd expansion, 3 abbreviazione ufficiale della moneta euro (dal $1^{\circ}$ gennaio 1999 in tutti gli Stati partecipanti), obbligatoriamente tutta maiuscola (official abbreviation of the euro currency, since 1 January 1999 in all participating countries, compulsory all upper case letters). We notice that the number is not written in bold and we also notice a long explanatory sentence providing information about the official abbreviation of the euro currency, followed in brackets by some additional information stating that the currency was adopted by all participating countries on the 1st January 1999 and followed by an orthographic remark, i.e. obbligatoriamente tutta maiuscola (compulsory all upper case letters) stating that the abbreviation is obligatorily written in upper case letters.

\section{Example 12}

FNAC $f r$. Fédération Nationale d'Achats des Cadres [Federazione nazionale d'acquisto dei quadri (quadri in senso aziendale), iniziale gruppo d'acquisto divenuto grande catena internazionale di negozi specializzati nella vendita al miglior prezzo di prodotti tecnologici: dischi, libri, fotografia, hi-fi, TV, ecc. e in prodotti culturali: mostre, incontri e dibattiti, fondata del 1954 a Parigi].

Example 12 is interesting as it was originally a French abbreviation. The dictionary entry is composed of the entry word in bold, followed by the language qualifier, fr. and the French expansion. We notice two types of brackets; the dictionary entry starts with square brackets where a detailed explanation in Italian, functioning as encyclopaedic data of the term, is given. In the first part an Italian equivalent of the expansion is provided, namely Federazione nazionale d'acquisto dei quadri (National purchasing federation of tables), followed by an additional explanation of the Italian term quadri, namely (quadri in senso aziendale) (tables in the economic sense) in brackets and in italics, and followed by the longer explanation of the abbreviation FNAC provided in italics, iniziale gruppo d'acquisto divenuto grande catena internazionale di negozi specializzati nella vendita al miglior prezzo di prodotti tecnologici: dischi, libri, fotografia, hi-fi, TV, ecc.e in prodotti culturali: mostre, incontri e dibattiti, fondata del 1954 a Parigi (initial purchasing group that has become a large international chain of stores specialising in the sale of technological products at the best price: records, books, photos, hi-fi, TV, etc. and in cultural products: exhibitions, meetings and debates, founded in 1954 in Paris).

Examining Righini's work we have to say that it is a great and fairly systematically compiled work. In the dictionary the language and field qualifiers are present when needed and systematically, foreign expansions are given after the 
head word and are followed by the explanation or translation, provided in Italian, the latter is provided in brackets and in italics, additional information is also provided in brackets (also square brackets) and in italics. In the dictionary we encountered some compilation issues that are provided above. Translations and additional information or encyclopaedic data, as well as cross-references and in some cases field qualifiers, are among the linguistic issues that cause confusion.

\section{Dizionario delle Sigle e degli Acronimi (Malossini 1999)}

Dizionario delle Sigle e degli Acronimi (Malossini 1999) is an Italian dictionary of abbreviations that has over 8,000 Italian and foreign abbreviations and over 11,000 expansions. The dictionary extends to over 300 pages. In the short preface the author explains that the abbreviations predominately come from the field of informatics, telecommunication, institutions, associations, economy and transport. Prior to the preface there is no list of language and field qualifiers provided, the main reason being the fact that such elements are not included in the dictionary entries even if the dictionary does include foreign abbreviations in addition to Italian, namely well-known examples from English, i.e. BBC; German, i.e. ABS; Latin, i.e. a.a. etc. As seen from the dictionary entries, the foreign abbreviations are not translated, and no additional explanation or description is provided. The composition of the dictionary entry is simple, the abbreviation provided in bold is followed by a list of alphabetically ordered expansions, which are separated by a black dot. Here and there, within the dictionary entries, we notice in brackets the occurrence of additional information provided as simple words or short patterns.

\section{Example 13}

A Airbus Industrie $\bullet$ Alfiere (scacchi) $\bullet$ Alta pressione (meteoroliga) • Area (geometria) • Assicurata (poste) • Asso (carte da gioco) • Associazione $\bullet$ Atomica (bomba) • Atto (teatro) $\bullet$ Australe $\bullet$ Austria $\bullet$ Automotrice $\bullet$ Autore $\bullet$ Autostrada $\bullet$ vitamina

In example 13 we notice a typical dictionary entry, composed of alphabetically ordered expansions, all written with a first capital letter, except for the last expansion, i.e. vitamina (vitamin), as it represents a set phrase. The expansions are separated by a black dot and in some cases there is additional information provided in brackets, usually a word or phrase that gives the reader the basic information of the field of usage of the abbreviation, i.e. Area (geometria) • Assicurata (poste) • Asso (carte da gioco). 


\section{Example 14}

AC Access Control • Aeroclub • Air Canada (cod. IATA) • Air Conditioning • Alternating Current $\bullet$ Assegno circolare $\bullet$ Automatic Computer $\bullet$ Aviazione civile $\bullet$ Azione cattolica

As seen in example 14 there are also foreign expansions present within the dictionary entry, for English, i.e. Air Conditioning, Alternating Current, etc. and for Italian, i.e. Aviazione civile (Civil Aviation), Azione Cattolica (Catholic Action), but there is no information concerning the language qualifier prior to the expansion and also no translation of the foreign expansions into Italian and no explanations. Those were all elements that we encountered in Righini's dictionary (2001). In Malossini's (1999) work we notice the introduction of additional information in brackets within the expansion Air Canada (cod. IATA), stating that it is an international code.

\section{Example 15}

af Afganistan (cod. Internet)

In example 15 we notice the appearance of additional information in brackets, i.e. (cod. Internet), codice Internet, in English internet code.

\section{Example 16}

BBPR Banfi, Barbiano, Peressutti e Rogers (studio di architetti e urbanisti)

Example 16 draws our attention as we notice that the expansion is composed of surnames and in brackets there is an explanation (studio di architetti e urbanisti) (office/group of architects and urban planners) that functions as additional information, translated into English it is (a group of architects and urbanists).

\section{Example 17}

BBS Bulletin Board System [Service]

bcc blind courtesy [carbon] copy

As seen in example 17 within the entries we also notice some cases where square brackets are used, i.e. [Service] and [carbon]. The function of the square brackets is to give the reader the information that both words are used, namely system and service within the expansion of the abbreviation BBS and carbon and courtesy within the expansion of the abbreviation bcc. 


\section{Example 18}

CEKA C'resvyciàjnaja komissija (polizia di Stato sovietica)

In example 18 we encounter a Russian abbreviation. The expansion is provided in Russian and is followed by an explanation in brackets (polizia di Stato sovietica) stating that it is the denomination of (militia in the Soviet Union).

Malossini's Dizionario delle Sigle e degli Acronimi (1999) was the first contemporary dictionary of Italian abbreviations, composed of a simple entry structure where the reader misses apart from the language and field qualifiers mainly the translations of foreign abbreviations. Just two years after Malossini's publication Righini's (2001) Dizionario di Sigle Abbreviazioni e Simboli - DidiSi was published, having a more detailed entry structure being composed of language and field qualifiers, translations and additional information. Being published twenty years ago both works needs to be improved and updated in order to cope with the current abbreviations. A digitalized version, one that could be periodically updated, of both dictionaries is also seen as a positive improvement on both works.

\section{Other Italian dictionaries of abbreviations}

Among other dictionaries of Italian abbreviations, it is worth mentioning the Dizionario di abbreviature latine e italiane (Cappelli 1899) which is more of a diachronic dictionary meant for individuals who are interested in readings and transcriptions of medieval texts and documents, both in Latin and Vulgar Italian, because in the two languages the system of abbreviations is widely used due to the complexity of the medieval system of abbreviations. The dictionary extends to 673 pages, starts with a long preface and is followed by the dictionary of Latin and Italian abbreviations.

We encounter other abbreviations in paper monolingual Italian dictionaries, included in a more or less extensive appendix at the beginning or the end of a dictionary, as is the case of Zingarelli (Zingarelli 2000), where we encounter 23 pages of abbreviations in the appendix at the end of the dictionary. There are approximately 4,000 dictionary articles. Some examples are presented below.

\section{Example 19}

\section{CAF}

1 Commissione d'Appello Federale (gioco del calcio) 2 (comm.) fr. Coût, Assurance, Fret (costo, assicurazione, spesa) $=\mathrm{CIF}, \mathrm{CAN} 3$ (chim.) Cloranfenicolo 4 Craxi Andreotti Forlani (alleanza politica tra DC e PSI della fine degli anni '80) 5 fr. Club Alpin Français (Club alpino francese) 
As seen from example 19 the dictionary entry is composed of several expansions that do not follow the alphabetical order of inclusion. Expansions are introduced with Arabic numbers written in bold and italics. As seen from the dictionary entry the field and language qualifiers are included after the Arabic number and prior to the expansions, both in italics and abbreviated, field qualifiers are in brackets. As seen from example 19 foreign abbreviations are included within the dictionary entry, i.e. Coût, Assurance, Fret (costo, assicurazione, spesa), (cost, insurance, expense), after the foreign expansion there is the Italian translation present in brackets, followed by the synonymous foreign abbreviation after the symbol =, i.e. CIF, CAN. Some additional information is also present within the 4 th expansions in brackets, i.e. (alleanza politica tra DC e PSI della fine degli anni '80) (political alliance between DC and PSI in the late 1980s), giving additional meaning to the expansion of the abbreviations composed entirely of surnames. In the monolingual online dictionary Garzanti (2021), Italian and foreign abbreviations are included among the dictionary entries, as seen from example 20.

\section{Example 20}

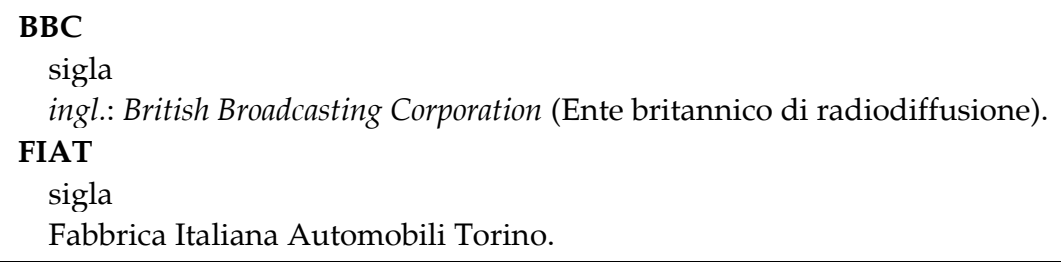

As seen from example 20 the dictionary entry is simple, composed of the headword written in bold and followed by the denomination sigla, in English abbreviation. ${ }^{1}$ Within the dictionary entry the language qualifiers are included, i.e. ingl., inglese (English) abbreviated and written in italics and followed by colon and the expansion. Foreign expansions are written in italics and followed by the explanation or translation in brackets, Italian expansions are not written in italics and there is no description or additional information given.

Within the bilingual encoding dictionaries, it is worth mentioning the Veliki slovensko-italijanski slovar (Šlenc 2006) where we do not encounter abbreviations, except for lexical and linguistic ones, i.e. ital., (Italian). More abbreviations are encountered in the bilingual decoding dictionary Veliki italijanskoslovenski slovar (Šlenc 1997) where in the appendix we find a list of approximately 1,000 abbreviations. The dictionary entry is simple, as seen in example 21 the expansions written in bold are alphabetically ordered and introduced by Arabic number in bold and followed by the Slovene translations. In the dictionary entry AA we notice the occurrence of abbreviated field qualifiers, i.e. MAT. (mathematics) GEOGR. (geography) prior to the expansion. In the dictionary 
entry A.C.I. we also notice the occurrence of gender denomination prior to the expansions, i.e. f, for femminile, (feminine) and $m$, for maschile, (masculine).

\section{Example 21}

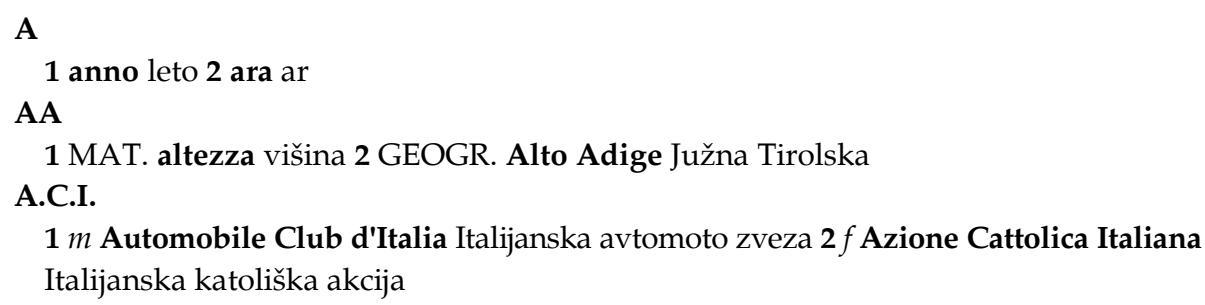

The Italian-Slovene dictionary entries of the Slovene Contemporary Dictionary of Abbreviations

The aim of the paper is to observe how are abbreviations included into the Italian dictionaries of abbreviations, monolingual dictionaries and in bilingual dictionaries in tandem with Slovene, and use the examples of good practice in the compilation of the Slovene Contemporary Dictionary of Abbreviations (Kompara Lukančič 2017) that has been a topic of lexicographic interest in Slovenia since the first attempts from 2006 and 2011 were prepared, namely the Slovarček krajšav (2006) and the Slovar krajšav (2011).

The Slovene Contemporary Dictionary of Abbreviations is an alphabetically ordered dictionary that comprises of approximately 10,000 dictionary entries and over 30,000 expansions (Kompara Lukančič 2017) and is based on the two dictionary attempts from 2006 and 2011. The dictionary was also compiled thanks to the development of the algorithm for automatic recognition of abbreviations and abbreviation's expansions in electronic texts (Kompara Lukančič 2011), followed by the transfer of all dictionary entries to the Termania dictionary mask, and later transferred to two word documents, the first comprising of abbreviations of Slovene origin and the second comprising of foreign abbreviations, i.e. Italian, Latin, Spanish, English, etc. The first data base, namely the one comprising of Slovene abbreviations is currently in the revision process and we estimate it to be ready for publication in late 2021.

Within the compilation of the dictionary some steps were automatised, some, mainly due to its complexity, were manual. Due to its complexity, field qualifiers were manually added to the expansions. The editors, who are specialists in dictionary editing and compilation, prepared a list of abbreviated field qualifiers following steps from bilingual dictionaries (also Šlenc 1997, 2006) and determined the rules when an expansion needs the field qualifier. The entirely automatised step in compilation is found in language identification where the Presis analyser was used (Kompara Lukančič and Holozan 2011). 
The analyser functions in the following way: in the first stage the expansion is sent to the Slovene analyser. If the analyser is successful, the language code "sl" is assigned; if not the language code "sl-x" is assigned (Slovene - to be manually checked). In cases where there is no code the Italian analyser is applied and if it is successful, the language code "it" is assigned, if not the language code "it-x" is assigned (Italian — to be manually checked). The same procedure is applied for all the languages included in the dictionary as a whole (Kompara Lukančič and Holozan 2011). The Italian-Slovene dictionary entries are part of the second data base, namely the one composed of foreign abbreviations. The extraction process was manual and automatic. For the automatic extraction of the Italian abbreviations, the online newspaper Delo was used. Monolingual, bilingual, specialised dictionaries and encyclopaedias were used for the manual extraction of the Italian abbreviations. The abbreviations were included in the dictionary if they matched with the expansions and occurred at least twice.

In presenting the Italian-Slovene dictionary entries of the Slovene Contemporary Dictionary of Abbreviations a random sampling method was used. The overall characteristic of all dictionary entries is the inclusion within the entries of abbreviations with more than one expansion, as seen in examples 22 and 28 where we encounter more than one expansion of the abbreviation. Following Righini's (2001) structure in adding translations, we decided that all Italian expansions are followed by the official translations or description and in several cases additional information is also provided, i.e. in examples 23 and 24 . The official translations are set translations retrieved from dictionaries, encyclopaedias, databases, web pages, the Slovenian orthography, and the Official Gazette.

As seen in the examples below from 22 to 28 , within the dictionary entries we notice the abbreviated language qualifiers, it., (Italian). The language qualifier it. is present within the dictionary entries due to the fact that within the dictionary part comprising of foreign abbreviations the expansions of the abbreviations are in different languages, namely for AA there are English and Latin expansions present within the foreign language abbreviations, but for the purpose of the present paper only the Italian ones are presented. Below a detailed description of the examples of the Italian-Slovene dictionary entries is presented.

\section{Example 22}

$$
\begin{aligned}
& \text { AA } \\
& \text { it.: altezza } \bullet \text { višina } \\
& \text { it.: Alto Adige (geo.) • Južna Tirolska }
\end{aligned}
$$

As seen in example 22 the dictionary entry is composed of two expansions, prior to the expansion there is the abbreviated language qualifier it., followed by a 
colon and the Italian expansion, when necessary the field qualifiers, i.e. (geo.), (geography) are included in brackets, following the mark $>$ there is the translation or equivalent in Slovene. A list of field and language qualifiers is provided prior to the preface of the dictionary.

\title{
Example 23
}

aff.

it.: affezionatissimo $\bullet$ vdani $\diamond \mathrm{v}$ pismih

In cases as demonstrated in example 23, the Italian expansion affezionatissimo, in English very fond, is followed by the Slovenian translation vdani, in English devoted, and after the symbol $\diamond$ also an explanatory sentence, $v$ pismih, in English in letters, which explains the usage of the abbreviation in correspondence.

\section{Example 24}

\author{
Agip \\ it.: Azienda Generale Italiana Petroli (ekon.) $\diamond$ italijanska naftna družba \\ ALITALIA \\ it.: Aerolinee Italiane Internazionali (let.) $\diamond$ italijanska državna letalska družba
}

In the dictionary entries from example 24, the expansions do not have an official translation, because the original abbreviations are proper names or names of a company, i.e. Agip, ALITALIA. To distinguish such cases from cases where we have official translations, we introduce a short and concise explanatory sentence after the symbol $\diamond$.

\section{Example 25}

\section{alla ted.}

it.: alla tedesca $\bullet$ po nemško

Among the Italian abbreviations there are also cases of joint prepositions and definite articles, namely the preposizioni articolate, articulated prepositions that are composed of prepositions combined with a definite article, i.e. alla ted. Some similar examples from Righini's dictionary were presented above in example 6. We wanted to highlight such cases providing an example, i.e. alla ted., being aware that such examples are limited. 


\section{Example 26}

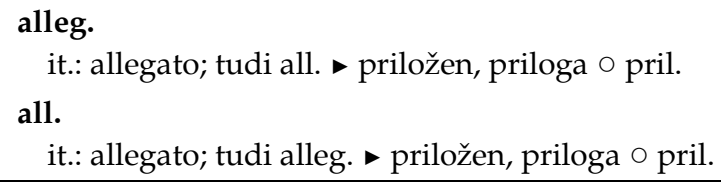

In example 26 we encounter synonymity of the two abbreviations, namely alleg. and all. In both dictionary entries the headword is followed by the abbreviated language qualifier it., colon and the Italian expansion, after semi colon and the word tudi, in English also, the synonymic abbreviation appears, i.e. all. and alleg., followed by the symbol used for translations and the Slovene translations, in this case we have two possible translations, priložen and priloga, in English attached and attachment. At the end of the entry there is also the Slovene equivalent abbreviation present, i.e. pril. introduced with the symbol $\circ$. As seen in example 26 the cross-reference of the foreign abbreviation is provided. In the Slovene part of the dictionary the cross-reference for pril. is also provided.

\section{Example 27}

B.U.

it.: Bollettino Ufficiale (prav.) • Uradni list o Ur. 1., Urad. 1., Urad. list, Ur. list, UL

In example 27 there is more than one Slovene equivalent abbreviation present, in such cases all cross-references are included as separate dictionary entries. The entry is simple, composed of language qualifier, followed by the Italian expansion and field qualifier in brackets, the Slovene translation is provided after the symbol $>$ and the Slovene equivalent abbreviations after the symbol $\circ$.

\section{Example 28}

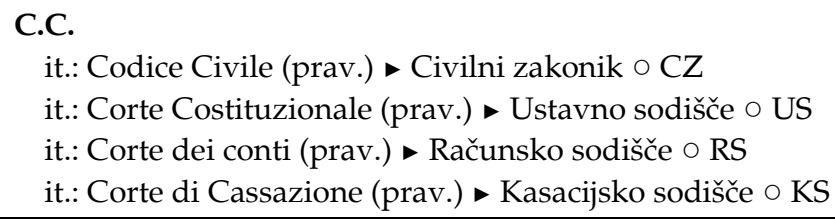

In example 28 we notice the occurrence of a series of Italian alphabetically ordered expansions that are accompanied with the abbreviated Slovene field qualifiers in brackets, i.e. (prav.), pravo in English law. The list of field qualifiers is provided prior to the dictionary prefaces. Due to the fact that all concepts of 
the Italian expansion also exist in Slovene, the translations are introduced with the symbol $\downarrow$ and followed by the official Slovene translations. Following the translations and introduced by the symbol $\circ$ are the Slovene equivalents of the abbreviations, namely CZ, US, RS, and KS. Within the Slovene part of the dictionary the cross-references of the previously mentioned Slovene abbreviations are provided among the dictionary entries.

\section{Conclusion}

Abbreviations are part of our everyday reality and are present in our lives and languages. They emerge out of current situations, i.e. COVID, relatively quickly on a daily basis. Some remain in a language forever; some disappear or are forgotten after the situation or concept is not an issue anymore. This fast occurrence and development of abbreviations calls to mind the necessity of up-to-date and functional abbreviation dictionaries. Unfortunately, as seen from the presented Italian dictionaries of abbreviations, too often the publication of a dictionary or a new edition of the already existing one does not occur in twenty years, as it is the case with the two Italian abbreviation's dictionaries (Righini 2001, Malossini 1999). The two analysed paper dictionaries differ in the number of entries included and characteristics of entries. We encounter inconsistencies among the inclusion and exclusion of translations, the language and field qualifiers, and additional information. In reference to the monolingual and bilingual dictionaries presented, a common characteristic is the fact that they are of limited entry number, because the abbreviations in such dictionaries are only included within the appendix and as such treated marginally. The overview of the position of abbreviations in all three types of dictionaries helped us prepare an adequate structure of the Italian-Slovene dictionary entries that are part of the Slovene Contemporary Dictionary of Abbreviations that is in preparation. Functional, contemporary, structurally adequate dictionaries of abbreviations are the result of combining the past and present concepts of lexicography.

\section{Endnote}

1. Denominations and consequently translations may differ from author to author, i.e. sigla can also be translated as acronym.

\section{References}

Cappelli, A. 1899. Dizionario di abbreviature latine ed italiane. https://archiviodistatotorino.beniculturali. it/strumenti/dizionario-abbreviature-italiane/

Date of Access: 5 February 2021.

Fajfar, T. and M. Žagar Karer. 2015. Strokovnjaki in drugi uporabniki terminologije kot naslovniki terminoloških slovarjev. Jezikoslovni zapiski 21(1): 7-21. 
Garzanti: https://www.garzantilinguistica.it/ricerca/?q=dizionario Date of Access: 5 February 2021.

Gložančev, A. 1980. Kratice v imenih delovnih organizacij. Jezik in slovstvo 26(2): 75-78.

Kompara Lukančič, M. 2006. Slovarček krajšav. Ljubljana: Inštitut za slovenski jezik Fran Ramovš ZRC SAZU.

Kompara Lukančič, M. 2009. Prepoznavanje krajšav v besedilih. Jezikoslovni zapiski 15(1-2): 95-112.

Kompara Lukančič, M. 2011. Slovar krajšav. Kamnik: Amebis, Termania.

Kompara Lukančič, M. 2017. Zasnova novega slovarja krajšav. Jezikoslovni zapiski 23(1): 77-92.

Kompara Lukančič, M. 2018. Sinhrono-diahroni pregled krajšav v slovenskem prostoru in sestava slovarja krajšav. Maribor. Univerzitetna založba Univerze.

Kompara Lukančič, M. 2020. An Overview of English Dictionaries of Abbreviations. Lexikos 30: 171-196.

Kompara Lukančič, M. and P. Holozan. 2011. What is Needed for Automatic Production of Simple and Complex Dictionary Entries in the First Slovene Online Dictionary of Abbreviations Using Termania Website. Kosem, I. and K. Kosem (Eds.). 2011. Electronic Lexicography in the 21st Century: New Applications for New Users. Proceedings of eLex 2011, Bled, Slovenia, 10-12 November 2011: 140-146. Ljubljana: Trojina, Institute for Applied Slovene Studies. https://elex2011. trojina.si/Vsebine/proceedings/eLex2011-17.pdf Date of Access: 5 February 2021.

Logar, N. 2005. Norma v slovarju sodobne slovenščine: zloženke in kratice. Družboslovne razprave 21(48): 211-225.

Malossini, A. 1999. Dizionario delle Sigle e degli Acronimi. Milano: A. Vallardi.

Righini, E. 2001. Dizionario di sigle abbreviazioni e simboli. Bologna: Zanichelli.

Šlenc, S. 1997. Veliki italijansko-slovenski slovar. Ljubljana: DZS.

Šlenc, S. 2006. Veliki slovensko-italijanski slovar. Ljubljana: DZS.

Termania: http://www.termania.net/

Date of Access: 5 February 2021.

Verovnik, T. 2018. Obravnava kratic v prenovljenih pravopisnih pravilih. Jezikoslovni zapiski 24(2): 43-54.

Verovnik, T. and N. Logar. 2006. O jeziku, stilu i utjecaju slovenskih tiskanih oglasa. Granić, J. (Ed.). 2006. Jezik i mediji: jedan jezik: više svjetova: 743-752. Zagreb, Split: Hrvatsko društvo za primijenjenu lingvistiku.

Zingarelli, N. 2000. Vocabolario della lingua italiana. Bologna: Zanichelli. 